\title{
Representing the Cultural Dimension of Meaning in Learner's Dictionaries - From the Perspective of Chinese EFL Learners in L2 Reception
}

Mei Xue, School of Law E Humanities, China University of Mining and Technology (Beijing), Beijing, P.R. China (meix99@yahoo.com)

\begin{abstract}
Meaning in dictionaries ranks as the most frequent data type consulted by language learners. An extensive range of devices have been developed to represent the meaning of lexical items in learner's dictionaries. Starting from interpreting foreign language learners' lexicographic needs in specific user situations, this paper aims to examine the implications of customizing definitions from the cultural perspective with specific reference to Chinese learners of English. The purpose of this paper is three-fold: i) to understand the status quo of the lexicographic practice of English learner's dictionaries in terms of representing the cultural dimension of a lexical item; ii) to interpret the impacts of foreign language learners' language and cultural background on their lexicographic needs in terms of cultural aspects in L2 reception; iii) to address the identified problems with present lexicographic practices through model articles. It is expected that the findings in this paper can shed some light on interpreting other ethnic groups of learners' lexicographic needs in different situations and contribute to improving the services of learner's dictionaries in the future as well.
\end{abstract}

Keywords: CHINESE EFL LEARNERS, CULTURAL DIMENSION, L2 RECEPTION, LEARNER'S DICTIONARIES

Opsomming: Die weergee van die kulturele dimensie van betekenis in aanleerderswoordeboeke - uit die oogpunt van Chinese EVT-leerders in L2resepsie. Betekenis in woordeboeke word beskou as die mees frekwente datasoort wat deur taalaanleerders opgesoek word. 'n Omvattende reeks hulpmiddels is ontwikkel om die betekenis van leksikale items in aanleerderswoordeboeke weer te gee. Hierdie artikel begin by die interpretasie van vreemdetaalleerders se leksikografiese behoeftes in spesifieke gebruikersituasies en beoog om die implikasies van die pasmaking van definisies uit 'n kulturele perspektief te ondersoek met spesifieke verwysing na Chinese aanleerders van Engels. Die doel van hierdie artikel is drievoudig: i) om die status quo van die leksikografiese praktyk van Engelse aanleerderswoordeboeke te verstaan ten opsigte van die weergee van die kulturele dimensie van 'n leksikale item; ii) om die uitwerking van vreemdetaalleerders se taalkundige en kulturele agtergrond op hul leksikografiese behoeftes te interpreteer ten opsigte van kulturele aspekte by L2-resepsie; iii) om die geïdentifiseerde probleme met die huidige leksikografiese praktyke deur modelartikels aan te spreek. Daar 
word verwag dat die bevindinge in hierdie artikel lig sou kon werp op die interpretasie van aanleerders uit ander etniese groepe se leksikografiese behoeftes in verskillende situasies en ook ' $n$ bydrae sou kon lewer tot die verbetering van die bruikbaarheid van toekomstige aanleerderswoordeboeke.

Sleutelwoorde: CHINESE EVT-LEERDERS, KULTURELE DIMENSIE, L2-RESEPSIE, AANLEERDERSWOORDEBOEKE

\section{Introduction}

Meaning in dictionaries ranks as the most frequent data type consulted by language learners. Numerous empirical studies on meaning determination resort to a specific learning task, namely text reception, production, and vocabulary learning to examine the effectiveness and efficiency of the dictionaries in different formats. Empirical findings generally show that it is still very challenging for foreign language learners to select the correct sense for a given context (Chan 2012: 135, 2014: 42; Ding 2015: 25-26; Nesi and Tan 2011: 90-91; Ptasznik and Lew 2014: 251). Undoubtedly, these empirical studies shed some light on understanding the problems with the present lexicographic practices, which is certainly helpful for devising models for future lexicographic practice. It is of paramount significance to make theoretic explorations on the critical areas like "the data to be included in these dictionaries, the structures to present and accommodate the data, the functions of these dictionaries and the way they should respond to the needs of their target users" (Gouws 2014: 157).

The emergence of e-lexicography has been refreshing the concept of dictionaries as well as the presentation of various data types in dictionaries (Tarp 2011). The digital medium offers golden opportunities to approximate the longstanding issue of customization in lexicographic practice (Verlinde and Peeters 2012: 148). However, the "current e-dictionaries too often do not live up to the expectations of their users", as "too many lexicographic e-products were developed without any influence from innovative theoretic suggestions" (Gouws 2014: 156-157). Quite a number of empirical studies show that the electronic dictionaries are not necessarily advantageous over their paper counterparts in terms of the provision of meaning to serve different learners (Chen 2010; Dziemianko 2012). Hence, it is a propitious moment to identify the target users' needs for meaning information in a specific user situation when discussing the provision of the customized services for users. Attention should also be paid to the profile of the target users, as the "users in general never need information in general" (Tarp 2009: 46).

This paper explores the implications of customizing definitions from the cultural perspective with specific reference to Chinese learners of English. Given the distance in L1 (Chinese) and L2 (English), Chinese learners may have some specific information needs for meaning in cultural aspects when they are engaged in different English learning activities. Starting from interpreting Chi- 
nese learners' particular needs for cultural information during L2 reception, this paper examines the status quo of the present lexicographic practices with English learner's dictionaries. Proposals are made for a more salient representation of the cultural dimension of the lexical items from Chinese learners' perspective. It is expected that the findings in this paper can shed some light on interpreting other ethnic groups of learners' lexicographic needs in different situations and contribute to the improved lexicographic practices in the future.

\section{Lexicographic Function and the Representation of Meaning in Learner's Dictionaries}

Dictionaries above all are utility tools conceived and produced to solve the practical problems arising in concrete situations (Tarp 2008), as the "lexicographic needs are not abstract needs, but are always related to the specific type of users who find themselves in a specific type of social situation" (Tarp 2009: 25).

\subsection{The Function of a Learner's Dictionary}

Different types of users may have different lexicographic needs, and the same users may have different needs in different situations. In this respect, the Function Theory of Lexicography distinguishes between four fundamental extralexicographical situations: communicative, cognitive, operative and interpretive situations (Tarp 2008, 2011). In the process of foreign language learning, foreign learners are frequently situated in communicative and cognitive situations. The communicative situations can be further specified into text reception in L2, text production in L2, translation from L1 to L2 or vice versa. There are fundamental differences between the communicative and cognitive situations in terms of foreign learners' information needs. In cognitive situations, "it is very difficult to obtain a clear idea of the exact information that the users need, and as a result, of the data required to provide this information" (Tarp 2011: 65), as learners' objective is to gain knowledge. On the other hand, in communicative situations, learners' needs are concrete. For example, learners in reception situations mainly consult dictionaries for meaning information to facilitate comprehension, whereas in production they may need grammatic and pragmatic information to help them properly use a lexical item.

The genuine function of a learner's dictionary is to satisfy foreign learners' needs in a specific language learning situation, but it is to be noted that there are always unpredictable information needs in additional situations, although such cases are relatively rare (Tarp 2011). In functional terms, the optimal dictionary is mono-functional (Bergenholtz 2011), but "this ideal is hardly ever commercially viable in printed dictionaries; it can be approximated in electronic dictionaries" (Heid 2014: 48). The electronic medium makes it possible to 
set up a repository of data for various lexicographic purposes (Heid 2014; Granger and Lefer 2016). The presentation interface of data can cater for the individual learners' needs in different situations. But, the electronic dictionaries may produce an "abundance of unstructured data" leading to the "information overload" and the ultimate "information death" (Gouws and Tarp forthcoming). Hence, efforts have to be taken to minimize the search-related costs (within a decent time) and comprehension-related costs (with low cognitive efforts) (Bergenholtz 2011; Tarp 2011). In other words, to warrant a successful information retrieval during dictionary consultation, the data on the interface of the article should be relevant and comprehensible, and the presentation of the required data should be explicit.

\subsection{The Representation of Meaning in Learner's Dictionaries}

Meaning is a central notion in lexicography and has been attracting wide discussion in the past thirty years. The digital medium has been extending the repertoire of defining devices available in printed age and may present a multimodal solution to definitions. But, without a coherent framework to guide how to employ the diverse defining devices to meet the target users' needs in concrete situations, the potential offered by technology can be of decorative value as shown in Lew and Doroszewska's (2009) study on animation. Foreign learners' difficulty in sense selection is still apparent as evidenced in numerous studies mentioned above, despite the availiability of various defining devices in electronic dictionaries.

Referring to a multitude of devices for definitions, Liu (2015) proposes a concept of multimodal definitions used for e-lexicography. According to Liu (2015), the linguistic function of meaning (i.e. ideational, interpersonal and textual) can be realized by technology in four dimensions (i.e. content, form, space and time). The multimodality definitions are mainly based on functional linguistics. But, it is to be noted that the notion of senses is different in lexicography and linguistics and there is a tenuous relationship between the lexicographic sense and linguistic notion (Lew 2013: 284-285). Functional linguistics is concerned about what language does and how it does so in a given context, whereas various linguistic data in a dictionary are combined to accomplish the function of the dictionary instead of the linguistic function in social contexts. Linguistic developments definitely contribute to the development of lexicographic tools, and the electronic medium may speed up the interactions between linguistics and lexicography. However, both the linguistic developments and technology potentials have to be interpreted from the lexicographic perspective and critically adapted for lexicographic practice. Hence, it tends to be arbitrary to claim that:

E-dictionaries can renew its information more frequently and easily than their print counterparts. This can help guarantee the recency and accuracy of meaning which prove to be the major concerns of users (Liu 2015: 255). 
The electronic dictionaries enjoy the advantages of updating the included data regularly, and the renewed data may satisfy some concerns of some users in some situations, but not necessarily the major concerns of users in different situations.

The electronic medium seems to put an end to the struggle over the tradeoff between the clarity and precision in the provision of definitions in paper dictionaries. But, there is a need to "find the balance between telling the fullest story and deciding what's useful for the average reader" (Fatsis 2015). In digital age, lexicographers have to decide what information is relevant to the target users' needs and how to present the relevant information explicitly. MD (Macmillan Dictionary) Online introduces a two-sentence policy to convey the conventional meaning and the connotative or pragmatic/cultural information in definitions. A similar approach is adopted by CED (Collins English Dictionary) Online. The addition of the information about the attitude or a motivation of a speaker to use a word is especially useful for foreign learners in text production. This has been explicitly stated by Stein (2002):

The lexicographic description of some words requires an explicit and precise description of the pragmatic situation in which they are used or in which the activity denoted by them is performed (95).

Pragmatic restrictions are useful to guide foreign learners' proper use of a L2 lexical item. On the other hand, in L2 reception contexts, they may encounter some objects or concepts typical of L2 culture and hence need the relevant cultural elaborations to facilitate comprehension. Learners' needs with regard to cultural aspects during $\mathrm{L} 2$ reception are authentic and deserve attention in lexicography. However, there is relatively little discussion in this respect. Therefore, this paper aims to examine the provision of cultural data, with specific reference to Chinese learners' needs arising in L2 reception. The purpose of this paper is three-fold: i) to understand the present lexicographic practice of English learner's dictionaries in terms of representing the cultural dimension of the lexical items; ii) to interpret the impact of the learners' language and cultural backgrounds on their needs with regard to cultural aspects during L2 reception; iii) to address the identified problems with proposals. It is to be noted that the online dictionaries referenced in this paper is for research purposes, not for an assessment of their popularity or quality.

\section{The Gap between Users' Needs and the Present Lexicographic Practice}

Words and expressions in a language are tinted with cultural dimensions, but there are degrees of culture-specificity. Some items are more culture-bound than others. For instance, the expression barefoot doctor is culture-loaded, describing a social phenomenon in China in a specific historical period. In contrast, the referent of a magpie is similar in different countries, but its associated symbolic meaning varies with different cultures. The loss of the track of the 
cultural allusion underlying a lexical item could lead to communication failures in cross-cultural contexts. Zgusta (1989) has stated:

[...] since language is embedded in culture, cultural data are important to the learner not only for steering his linguistic behaviour but frequently for choosing the correct lexical equivalent. Such cultural information can be understood in a broad way, Undoubtedly a good part of this information is of encyclopaedic character; be this as it may, it belongs to what the learner has to learn (3).

Culture can be universal as well as specific. People around the world share a common concept of New Year, but the specifications of New Year vary with different cultures in terms of its history, significance and rituals. The overlapping and discrepancies in cultural schema in L1 and L2 may facilitate or block foreign language learning. For example, the average German learners of English could have much more in common with English culture than the average Chinese learners. Hence, Chinese learners could have more needs for information typical of English culture than their German counterparts have in the process of learning English. Therefore, the inclusion and the presentation of the cultural data in a learner's dictionary should be considered with reference to the target users' language and cultural backgrounds.

\subsection{Chinese Learners' Difficulty in Comprehending L2 Culture-loaded Words}

Meaning data in learner's dictionaries help dictionary users smooth away the blocks to comprehension in L2 reception. But, when there is a wide discrepancy in the conception of an object or an idea in L1 and L2, a factual definition of the referent in L2 may be insufficient for solving the possible receptive problems. In such cases, L1 equivalents alone may not work effectively either. For instance, when foreign learners of English encounter the word robin and may have different information needs depending on their prior knowledge, reading skills, and the immediate reading context: i) the word robin is completely a new word, and they want to know what it refers to; ii) they may infer that the word robin refers to a kind of bird, but are curious to confirm their assumptions or prior knowledge about this type of bird; iii) they may have the inferences about the bird, but the given context demands the suggestive meaning and they cannot figure it out. To sum up, foreign learners of English, like Chinese learners may need the information about the denotative and symbolic meaning of a lexical item in L2 reception. When foreign learners are living in the cultural settings of the addressed language, they may also need to identify the referents for their daily life.

The definition "a small brown bird with a red chest" in CLD (Cambridge Learner's Dictionary) Online is sufficient for solving users' problems in the first situation above. On the other hand, the provision of a lexical remark in italics like "robins mostly appear in the winter and are commonly pictured on Christmas 
cards" in CD (Cambridge Dictionary) Online (see Figure 1) seems to fulfill Chinese learners' information needs in the third context above. However, this lexical remark still demands learners' efforts to abstract the implied message that a robin is a symbol of Christmas in the western culture. A click on the translation button in both CLD Online and CD Online will direct learners to the interface of the corresponding bilingual article in which four Chinese equivalents to robin are provided. However, if Chinese learners have limited zoology knowledge about the bird robin, these equivalent terminologies are no better than a short English explanation.

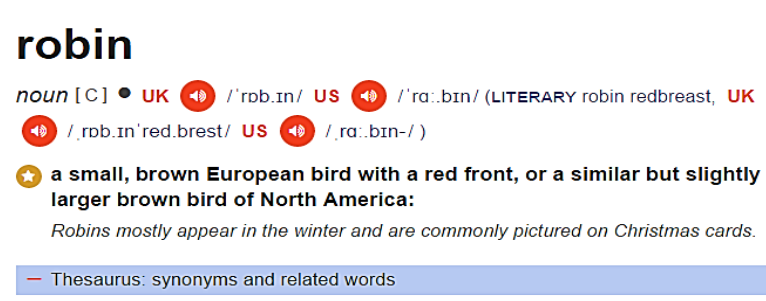

Figure 1: The article robin from $C D$ Online

In contrast, the cultural note in OALD (Oxford Advanced Learner's Dictionary) Online as shown below is quite explicit and spares learners' efforts to retrieve the overtones carried by robin. MD Online goes a step further by supplementing a pictorial illustration to help learners identify the referent in the physical world, which contributes to the cognitive learning of this word as well.

robin ...

\section{-Culture}

In Britain the robin, sometimes called robin redbreast, is strongly associated with Christmas and pictures of robins, especially in snow-covered gardens, are often used on Christmas cards.

Unfortunately, such a way of representing the cultural dimensions of a word is not a common practice in MD Online. The criteria for including such cultural elements are implicit and intangible. For example, the word chard is illustrated with a relevant picture, whereas no pictorial illustrations are used to explain artichoke, kale, Romanesco, and arugula, etc. It is strange that different defining policies are employed to describe these vegetables, given the fact that all these varieties of vegetable are foreign to people whose cultural backgrounds are distanced from European culture. For instance, the definition of artichoke "a round green vegetable with thick pointed leaves arranged close together in layers" from $M D$ Online almost means nothing to most Chinese learners, as they do not share the similar schema knowledge about this vegetable common to Europeans. Inevi- 
tably, the pragmatic information in the second sentence of the definition "After cooking it, you pull off each leaf and eat the soft bottom part" may not get across to Chinese learners at all. A picture can be much more effective than a thousand words, when it comes to describing something typical of one culture but foreign to other cultures. Lexicographers should take dictionary users' cultural background into account upon defining the L2 culture-loaded lexical items.

The distance between English and Chinese leads to a wide divergence of the reflective and social meaning of some words, like the words for colors, animals and numbers, etc. A magpie is "a bird with black and white feathers and a long tail" (from CLD Online) in physical terms, but its symbolic meaning is divergent in British and Chinese culture. In British culture, the magpie is thought to be in connection with bad luck, especially when you only see a magpie alone, whereas the symbolic meaning of a magpie takes on a bright note in the East. In China, the magpie is a symbol of good luck, joy, marital bliss and long lasting fortune. The different conception of a magpie in Chinese as opposed to English culture may elicit confusions in understanding if the given reading context calls for the cultural associations of this word. A learner's dictionary does not only need to pay attention to the lexical items with referents typical of L2 culture, but also those having different referential or connotative meanings in other language and cultures. It might be unrealistic to include various encyclopaedic information in a general English learner's dictionary, but it is feasible to let the dictionary raise users' awareness of divergent interpretations of the concerned lexical items in different cultures. However, none of the learner's dictionaries under examination seriously addresses the issues in this respect.

It goes without saying that the inclusion of cultural data is necessary for L2 reception. Equally important, the content of the cultural data should be relevant and revealing from the perspective of the target users. Take the cultural note on mockingbird in OALD Online as an example:

\section{mockingbird ... -Culture}

Many people believe it is morally wrong to kill one, and this idea was used in the novel To Kill a Mockingbird. It is also mentioned in several traditional songs and is the official state bird of Arkansas, Florida, Mississippi, Tennessee and Texas.

The starting point of this cultural note is to explain the allusion to mockingbird, but the content of the culture note may confound a foreign learner who has never read the book To Kill a Mockingbird. Such a circumlocutory explanation leaves dictionary users wondering why it is morally wrong to kill a mockingbird. Such a practice also occurs in $O D$ (Oxford Dictionaries) Online and $C D$ Online. For example, the article mistletoe states that it is traditional to kiss under the mistletoe. Given their limited knowledge about L2 culture, it is highly likely that average users insist on what this tradition means to people kissing under 
the mistletoe. Therefore, it is recommendable to make the cultural allusions apparent and revealing to foreign learners. If the explanations tend to be too complicated for such a short note, an external hyperlink to a further elucidation of the concerned topic can be provided as an option.

Suppose Chinese learners turn to bilingual solutions when they encounter the above-mentioned words. The search results from the most popular EnglishChinese online dictionaries like Haici, Jinshan Ciba and Youdao are rather depressing. The general practice of these online bilingual dictionaries is to provide one or several equivalents to robin (驹鸟, 知更鸟, 冻), artichoke (洋薊), curly kale (羽衣甘蓝), arugula (芝麻菜), Romanesco (罗马花椰菜), mockingbird (嘲斩) and mistletoe (葪寄生). The Chinese equivalents are nomenclatures from zoology and botany. These terms are quite abstract and foreign to average Chinese people and do not help reception at all, not to say become part of their knowledge. The encyclopaedic notes provided at the end of each article in Youdao tend to be incomplete and unreliable. Many of the illustrative examples in Jinshan Ciba are abstracted from unknown sources and thrive on various errors. The problems with the online English-Chinese dictionaries have been identified in earlier studies (Chen 2010; Ding 2008) and unfortunately have not been attended to much yet. In short, the most popular online English-Chinese dictionaries in China mainly focus on providing lexical equivalents and translation of example sentences, leaving the cultural dimension of English lexical items almost untouched.

\subsection{Chinese Learners' Difficulty in Comprehending Chinese Loanwords}

Chinese loanwords in English may also pose challenges to Chinese learners during text reception. Due to the varied source languages and different transcribing systems, Chinese learners may experience difficulty in identifying these English words of Chinese origin, for example bok choy, cheongsam, chow mein, chop suey, choy sum, fan tan, dim sum, ho-ho, kowtow and pekoe, etc. The word Chinese is frequently used as a synonym to Mandarin, but linguistically, Chinese is an umbrella term encompassing a number of regional varieties called fang yan (dialects) in China, each with its own sub-varieties: Mandarin, $\mathrm{Wu}, \mathrm{Gan}$, Xiang, Hakka, Yue, and Min. Mandarin Chinese/Putonghua. Cantonese and Amoy are the main source languages for Chinese words entering English. It is to be noted that Chinese dialects are not all mutually intelligible. This means that most of the established Chinese loanwords of Cantonese origin maybe foreign to the majority of Chinese speakers in China (Yang 2009: 102).

Xia and Zhai (2016: 13-14) identify four problems with the definitions of Chinese loanwords included in OALD8 (Oxford Advanced Learner's Dictionary in its 8 th edition): the lack of indicating regional and referential differences, the missing denotative meaning and the definitions not being included. The referential differences are mainly caused by the inroad of Chinese loanwords into English. For example, chop suey is of Cantonese origin, referring to "a Chinese- 
style dish of small pieces of meat fried with vegetables and served with rice" (in OALD Online), whereas its Chinese equivalent zá sui (杂碎) in Mandarin (from bilingual dictionaries like Haici, Jinshan Ciba and Youdao) refers to a dish of cooked entrails of cattle or sheep. The word dim sum is also of Cantonese origin specifically referring to Cantonese snacks or pastries in English, whereas its Chinese equivalent diăn xin (点心) in Mandarin Chinese covers various snacks from different parts of China. As illustrated, the referential meaning of some Chinese loanwords are greatly restricted to their source language. Therefore, it is preferable for lexicographers to mark the regional restrictions in the definition section; otherwise, it may cause conceptual confusion in different receptive contexts. In English-Chinese dictionaries, it is also necessary to supplement the regional restrictions in definitions or explanatory notes to raise Chinese learners' awareness of referential differences in different cultures.

The close examination of the definitions of kowtow in OALD Online, MD Online, CLD Online and CD Online shows that the objective description of the traditional Chinese custom is omitted, which fails to fully represent the conception embodied in the word kowtow. Figure 2 below shows that only the metaphorical meaning of kowtow is presented in CED Online for learners of English.

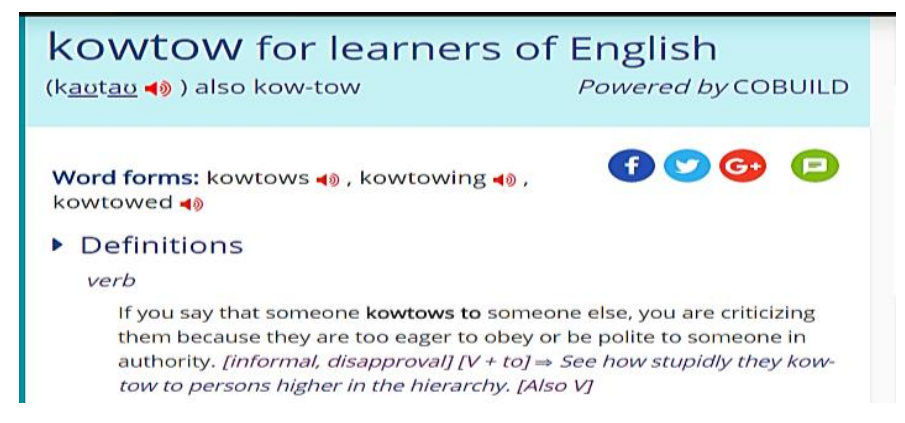

Figure 2: Part of the article kowtow from CED Online

Kowtowing is a solemn rite paying respects to the senior or the superior in ancient China and is still performed in many significant social situations (i.e. the Chinese Spring Festival, Qingming Festival, and wedding ceremony) today. The unanimous omission of the literal explanation of the kowtowing custom in MD Online, OALD Online and CLD Online is inexplicable. CED Online designed for general purpose does offer an explanation of "to touch the forehead to the ground as a sign of deference". However, this definition does not explain the cultural contexts in which the ritual takes place. The omission of the literal meaning of kowtow and the lack of contextual information on the ritual of kowtowing may not influence Chinese learners or the learners sharing the same cultural schema, but it would impose the misconception of this custom on other ethnic groups of learners in receptive and cognitive situations. 


\subsection{The Problems with the Present Lexicographic Practice}

The detailed analysis in this section shows that the online dictionaries do not actively respond to foreign learners' needs in cultural dimensions. Specifically, the following aspects deserve attention. First, the inclusion of cultural data tends to be incidental and unpredictable. Second, the content of the cultural data is not explicit and demands many efforts in the process of information retrieval. Third, cultural differences in denotative or connotative dimensions should be attended to, to elicit foreign learner's awareness in L2 reception. Fourth, the conceptual meaning of Chinese loanwords in Chinese and English deserve due attention. Last, but not the least important, bilingual solutions should be clearly defined in foreign language learning contexts.

\section{Proposals}

This section demonstrates some proposals through model articles for future lexicographic practice, highlighting EFL learners' needs with regard to cultural aspects during L2 reception. Chinese learners of English are taken as target dictionary users to illustrate customization of lexicographic assistance demonstrated in some model articles. The proposals are mainly targeted at online dictionaries and can be adapted for dictionaries in other forms.

\subsection{Presenting the Relevant Cultural Data Explicitly}

When the conception represented by a L2 lexical item does not belong to the cultural universe of foreign learners', it is necessary to make such part of cultural data apparent to them and help them into the cultural dimension associated with the word for better understanding. Take the word mockingbird as an example:

mockingbird a small white and gray North American bird that copies the songs of other birds.

-Culture: mockingbird is able to mimic almost any sound it hears, symbolizing joyfulness, cleverness, playfulness, and communication. In the book "To Kill a Mockingbird", mockingbird symbolizes innocence. It is morally wrong to kill a mockingbird, as it is neither harmful nor destructive, but only makes music for people to enjoy.

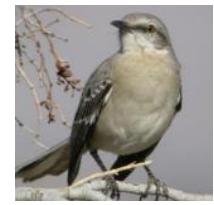


In the above model article, the definition, pictorial illustration and culture note are combined to enhance comprehension. The pictorial illustration shows the referent and help learners identify this bird in reality, which also contributes to cognitive learning. The culture note explicitly states the universal symbolic meaning of mockingbird as well as its metaphorical significance in the wellknown book in association. The culture note in the model article is collapsed below the definition with a guide word Culture. All the information can be accessed through a click. For learners who rely on their mother tongue for text reception, the L1 equivalents together with the above-mentioned data should be supplemented for them to identify the referent for cognition purposes and future communication in L1, as the provision of only a L1 equivalent is very challenging for learners with limited knowledge about birds.

In the model article mistletoe, the cultural dimension of mistletoe finds its expression in definitions, pictorial illustrations and the culture note. Pictorial illustrations are not immediately presented on the interface out of concern that learners may be either interested in the plant on the tree or the plant as a Christmas decoration. Learners can access the picture of mistletoes growing on trees or being made as Christmas decorations by clicking the link to pictures. The culture note falls into two parts: the legends associated with mistletoe and the explanatory note about the tradition of kissing under the mistletoe. The metaphorical meaning of kissing under the mistletoe will be explicitly stated to resolve the possible questions about this tradition.

mistletoe a parasitic plant that grows on the branches or trunks of other trees and is often used as decorations at Christmas.

+For Pictures

- Culture

+ Legends

+ kissing under the mistletoe

The model article artichoke below is showing the possible treatment of the words referring to the objects or ideas common to L2 culture, but foreign to other cultures. A pictorial illustration of artichoke in combination with the pragmatic information in the definition clearly indicates what kind of vegetable artichoke is and how it can be cooked in general. The detailed cultural information about this vegetable is folded in the cache with a symbol icon "+" when needed. The second edition of Longman Dictionary Of Contemporary English has long ago stressed that "[t]he illustrations and the definitions work together to ensure that important language points and aspects of Western culture are explained in the clearest possible way" (F49 as cited in Stein 1991: 106). For those objects having varieties, like kale, the pictorial illustrations of the common curly kale can be presented for general understanding. In an online EnglishChinese dictionary, it is also necessary to supplement the Chinese equivalents like 洋薊, 朝鲜蓟, 菊芋 with pictorial illustrations. By knowing the name of the 
vegetable in their mother language, foreign learners could feel much confident in future communication on this topic.

artichoke: boil this vegetable in salted water or steam it, then pull off each leaf and eat the soft bottom part.

+More
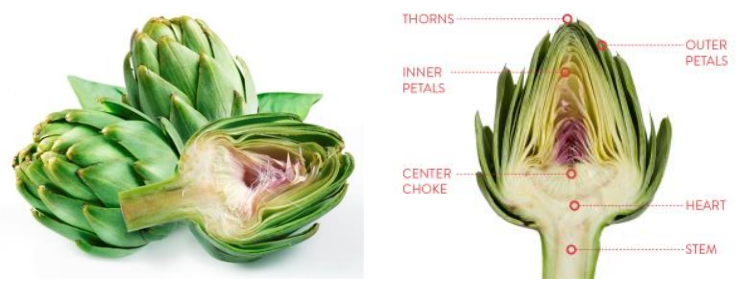

\subsection{Presenting the Information about Cultural Differences}

To deal with the cultural dimensions of lexical items, Bergenholtz and Agerbo (2014: 498) propose that the meaning elements be mainly distributed in three fields, namely a main meaning field, a lexical remark and a synonym remark. There is a risk to have some information overlapped in the three fields as shown in their given example of swastika (see Bergenholtz and Agerbo 2014: 500). The given example has addressed the cultural implications of swastika in German and India, but omitted its significance in Chinese culture. This present paper proposes that the definition part focus on the general meaning of the lexical item, whereas the lexical remark part elaborates the cultural differences. Moreover, the function of the dictionary plays a role in determining the contents of the lexical remarks. For text reception purposes, the lexical remark focuses on describing the diversified dimensions of the word in different cultures. In contrast, for production purposes, lexicographers need to go beyond the mere factual description of the cultural significance embodied in the lexical items and give explicit suggestions to guide learners to use the words properly or behave themselves appropriately in social contexts.

In the case of magpie, a contrastive presentation of the cultural allusions in Chinese and British culture would be favorable for L2 reception and cognition. For example:

magpie ...

-Culture: In British culture, magpies are believed in different numbers to foretell death, a funeral, and bad luck. The popular saying about magpies: One for sorrow. Two for mirth. Three for a wedding. Four for death or birth, depending on the origin. In Chinese culture, magpies symbolize good luck, joy, marital bliss and long lasting fortune. 
The content of the culture note in the model article is intended to raise the users' awareness of conceptual differences in British and Chinese culture and minimise possible confusion during L2 text reception due to their own cultural backgrounds.

\subsection{Addressing the Problems with Chinese Loanwords in English}

Depending on the problems Chinese learners have with loanwords during reception, the lexicographic assistance can be diverse. First, when the comprehension difficulty is caused by the old transcribing systems, a pinyin-based equivalent can be a solution. For example, ti-tzu is dí zi (笛子); kylin is qí lín (麒麟). As these objects and concepts are typical of Chinese culture, it is recommended that illustrations and explanations should be provided for learners with different cultural backgrounds. If the word has symbolic meaning or is associated with traditional stereotypes in Chinese culture, short explanatory notes are needed. Second, when the referential difference is caused by source languages of Chinese loanwords, an explanatory note or a reminder is necessary to clarify the divergences. Therefore, the Chinese equivalent to dim sum is not diăn xin (点心), but yuè shì diăn xin (粤式点心). The additional regional restriction yuè shì (奥式) demonstrates that dim sum is of Cantonese origin. This practice has been adopted in many English-Chinese online dictionaries. Third, when the same objects represented by the Chinese loanwords take different names in different geographic areas in China, the L2-L1 solution should take into account the variant nomenclatures. For instance, bok choy in the northern parts of China is called yóu cài (油菜), whereas it is called xiăo bái cài (小白菜) in the southern part of China. And yóu cài (油菜) in South China normally refers to the rapeseed plant. Last, the cultural dimensions embodied in Chinese loanwords should be interpreted in Chinese social contexts, as illustrated in the case of kowtow.

Given the increasing contact between Mandarin Chinese and English, spurred by the fast economic development in China, many pinyin-based words and expressions are used in the western media and some of them have entered English dictionaries, like fengshui, laogai, guanxi, etc. There are trends of replacing the established Chinese loanwords with pinyin-based words. For example, dumpling is jiaozi, ang pow is red packet, and kung fu is wushu. The emblematic traditional dress worn by Chinese women is called cheongsam (of Cantonese origin) or qipao (of Mandarin origin). Xia and Zhai's (2016) criticism of the mix-up of conceptual differences with regard to cheongsam and qipao in OALD8 is partially true, given the historical usage of cheongsam. But, the current usage of cheongsam has conformed to the conception of qipao as shown in the mainstream media in China and the western world, referring to the symbolic traditional dress worn by Chinese women (Yang 2009). A search in Ngram Viewer indicates that the use of qipao has been rising steadily and quickly since 1980s and is approximating the usage frequency of cheongsam. 
Given the above understanding, it is preferable to explicitly state the referential meaning of cheongsam in contemporary and historical contexts to help dictionary users cope with possible receptive situations.

The model article below shows a bilingual solution to reception problems, presenting the current usage of cheongsam and its original meaning respectively. The first part includes the variant expression, L1 equivalent, definition in L2 and the culture notes. The culture notes fall into two parts: the pictorial illustrations of different types of cheongsam/qipao and the pragmatic information about how to dress up properly with regard to cheongsam/qipao. The illustrations of various qipao are used to help learners identify the referents and raise their awareness that qipao comes in diverse styles. And dressing-up constitutes another dimension of the concept of qipao in Chinese culture, which is much more relevant to cognitive learning than to reception, and help learners dress up qipao properly in relevant social situations. These two categories of information are folded under the guideword Culture for learners' further needs and will not appear on the immediate interface. The second part presents the referential meaning of cheongsam in old times and indicates the regional label. The usage label old is meant to remind learners that this original meaning is old-fashioned and not in current use. An external link is provided for further knowledge of the garment for both females and males. For reception purposes, it is preferable to give both cheongsam and qipao headword status, whereas cross-references between these two items are required to help with productive purposes. It is a pity that none of the learner's dictionaries mentioned in this study has chosen qipao as a lemma, although OD Online and OED online have granted it main entry status.

\section{cheongsam}

1. =qipao, 旗袍:

The curve-accenting, body-fitting Chinese one-piece dress with side slits.

\section{- Culture}

+ qipao types (pictures)

+ dressing up qipao: hairstyles, shoes, and accessories

2. (old, Cantonese ) =cheong sam/chang shan, 长衫:

a long garment for both men and women

+ pictures

The use of a L1 equivalent in this model article is aimed to help learners quickly solve their reception problems or confirm their intended ideas in production situations. Certainly, the L1 parts can be removed or augmented depending on the targeted learners' L2 proficiency level. This model article is demonstrating the possibilities of inserting L1 facilitating props for learners when needed. This paper holds that L2-L1 bilingual solutions should not be reduced to the expedient provision of equivalents. The conception of bilingual dictionary 
is far more than furnishing semantic-pragmatic equivalents (Tarp 2008). Some recent explorations have been made to define the concept of bilingual learner's dictionaries (Granger and Lefer 2016; Halpern 2016). Given the focus of this paper, no elaboration is made in this respect.

\subsection{Summary}

As stated at the beginning, the devices used to represent the meaning of lexical items are diversified, including definitions, examples, equivalents, illustrations, usage notes, usage labels, etc. In many cases, different types of data are required to be combined to help dictionary users comprehend the meaning of the concerned lexical items in different contexts. The model articles in this section demonstrate the possibilities of catering for EFL learners' specific needs with regard to cultural aspects during L2 reception. Highlights are attached to the cultural differences in the conception of the words in L1 and L2 and the concepts typical of L2 culture. Chinese learners' particular problems with English words of Chinese origin are also addressed. The model articles have highlighted the significance of pictorial illustrations when it comes to elucidating the objects or concepts typical of L2 culture. Although technology has extended the concept of illustrations to graphs, diagrams and photographs, the detailed principles of using illustrations presented by Stein in 1991 are still worth careful consideration in terms of meaning representation. Otherwise, the use of illustrations can be superfluous.

\section{Conclusion}

This paper has described Chinese learners' information needs with regard to cultural aspects during English reception and reveals the deficiency in the present lexicographic practice in this respect. During L2 reception, foreign learners are mainly exposed to the cultural importance of the concepts reflected in L2 lexical units. On the other hand, they are also restrained by their own world knowledge acquired in their mother tongue/L1. Learners' needs for lexicographic assistance with regard to cultural aspects are authentic and imminent in particular contexts. Admittedly, foreign learners can resort to specific reference works for a profound understanding about the culture of the addressed language. But, for the cultural dimensions of a specific lexical item required in an immediate situation, average learners would turn to dictionaries for a quick solution. Therefore, it is essential to include the relevant cultural data in English learner's dictionaries to assist foreign learners of English in different situations.

This paper shows that the inclusion of cultural data, as well as the content of the cultural data should not only rest with the schema of the users within the cultural scope of the addressed language, but also those outside the cultural 
circle of the addressed language. It holds true that the digital media has provided great potential for reference works which will serve users' needs more effectively than their print-bound predecessors (Gouws and Tarp forthcoming). However, to serve users' needs effectively calls for a more user-oriented lexicography (Verlinde and Peeters 2012: 162). The medium of a dictionary may alter data quantity, storage and presentation, but never change the quality of the data required to realize the genuine function of the dictionary. This paper has explored the possibilities of customizing lexicographic assistance with regard to cultural aspects during L2 reception, with reference to Chinese learners and advocates further discussion on other ethnic groups of learners in a wider scope of user situations.

\section{Acknowledgements}

I would like to thank Professor Sven Tarp for his insightful comments. Special gratitude also goes to Dr. Hugues Steve Ndinga-Koumba-Binza and two anonymous reviewers for their constructive suggestions for improvement. This research is funded by China Scholarship Council (Grant No. 201606435015).

\section{References}

\section{A. Dictionaries}

Cambridge Dictionary Online: http://dictionary.cambridge.org/

Cambridge Learner's Dictionary Online: http://dictionary.cambridge.org/dictionary/learner/

Collins English Dictionary Online: https: //www.collinsdictionary.com/

Haici: dict.cn

Jinshan Ciba: http: //www.iciba.com/

Macmillan Dictionary Online: http: //www.macmillandictionary.com/

Oxford Advanced Learner's Dictionary Online: http://www.oxfordlearnersdictionaries.com/

Oxford Dictionaries of English Online: https: //en.oxforddictionaries.com/

Oxford English Dictionary Online: http: //www.oed.com/

Youdao: http: //dict.youdao.com/

\section{B. Other literature}

Bergenholtz, H. 2011. A Dictionary is a Tool, a Good Dictionary is a Monofunctional Tool. FuertesOlivera, P.A. and H. Bergenholtz (Eds.). 2011. e-Lexicography: The Internet, Digital Initiatives and Lexicography: 187-207. London/New York: Continuum.

Bergenholtz, H. and H. Agerbo. 2014. Meaning Identification and Meaning Selection for General Language Monolingual Dictionaries. Hermes: Journal of Language and Communication in Business 52: 125-139.

Chan, A.Y.W. 2012. The Use of a Monolingual Dictionary for Meaning Determination by Advanced Cantonese ESL Learners in Hong Kong. Applied linguistics 33(2): 115-140. 
Chan, A.Y.W. 2014. Using LDOCE5 and COBUILD6 for Meaning Determination and Sentence Construction: What Do Learners Prefer? International Journal of Lexicography 27(1): 25-53.

Chen, Y.Z. 2010. Dictionary Use and EFL Learning: A Contrastive Study of Pocket Electronic Dictionaries and Paper Dictionaries. International Journal of Lexicography 23(3): 275-306.

Ding, J. 2008. Bottom-up Editing and More: The e-Forum of the English-Chinese Dictionary. Bernal, E. and J. DeCesaris (Eds.). 2008. Proceedings of the XIII EURALEX International Congress, 15-19 July 2008: 339-343. Barcelona: Universitat Pompeu Fabra.

Ding, J. 2015. A Study of English Majors in a Chinese University as Dictionary Users. Lexicography ASIALEX 2: 5-34.

Dziemianko, A. 2012. On the Use(fulness) of Paper and Electronic Dictionaries. Granger, S. and M. Paquot (Eds.). 2012. Electronic Lexicography: 319-341. Oxford: Oxford University Press.

Fatsis, S. 2015. The Definition of a Dictionary. Slate Magazine. Accessed on 15 November 2016. http://www.slate.com.

Gouws, R.H. 2014. Article Structures: Moving from Printed to e-Dictionaries. Lexikos 24: 155-177.

Gouws, R.H. and S. Tarp. Forthcoming. Information Overload and Data Overload in Lexicography. International Journal of Lexicography. ecw030, https://doi.org/10.1093/ijl/ecw030.

Granger, S. and Marie-Aude Lefer. 2016. From General to Learners' Bilingual Dictionaries: Towards a More Effective Fulfilment of Advanced Learners' Phraseological Needs. International Journal of Lexicography 29(3): 279-295.

Halpern, J. 2016. Compilation Techniques for Pedagogically Effective Bilingual Learners' Dictionaries. International Journal of Lexicography 29(3): 323-338.

Heid, U. 2014. Natural Language Processing Techniques for Improved User-friendliness of Electronic Dictionaries. Abel, A., C. Vettori and N. Ralli (Eds.). 2014. Proceedings of the XVI EURALEX International Congress: The User in Focus, 15-19 July 2014: 47-61. Bolzano/Bozen: Institute for Specialised Communication and Multilingualism.

Lew, R. 2013. Identifying, Ordering and Defining Senses. Howard, J. (Ed.). 2013. The Bloomsbury Companion to Lexicography: 284-302. London: Bloomsbury Publishing.

Lew, R. and J. Doroszewska. 2009. Electronic Dictionary Entries with Animated Pictures: Lookup Preferences and Word Retention. International Journal of Lexicography 22(3): 239-257.

Liu, X.Q. 2015. Multimodal Definition: The Multiplication of Meaning in Electronic Dictionaries. Lexikos 25: 210-232.

Nesi, H. and K.H. Tan. 2011. The Effect of Menus and Signposting on the Speed and Accuracy of Sense Selection. International Journal of Lexicography 24(1): 79-96.

Ptasznik, B. and R. Lew. 2014. Do Menus Provide Added Value to Signposts in Print Monolingual Dictionary Entries? An Application of Linear Mixed-Effects Modelling in Dictionary User Research. International Journal of Lexicography 27(3): 241-258.

Stein, G. 1991. Illustrations in Dictionaries. International Journal of Lexicography 4(2): 99-127.

Stein, G. 2002. Better words: Evaluating EFL Dictionaries. Exeter: University of Exeter Press.

Tarp, S. 2008. Lexicography in the Borderland between Knowledge and Non-knowledge: General Lexicographical Theory with Particular Focus on Learner's Lexicography. Tübingen: Max Niemeyer.

Tarp, S. 2009. Reflections on Data Access in Lexicographic Works. Nielsen, S. and S. Tarp (Eds.). 2009. Lexicography in the 21st Century: In Honor of Henning Bergenholtz: 43-62. Amsterdam/ Philadelphia: John Benjamins.

Tarp, S. 2011. Lexicographical and Other e-Tools for Consultation Purposes: Towards the Individualization of Needs Satisfaction. Fuertes-Olivera, P.A. and H. Bergenholtz (Eds.). 2011. 
http://lexikos.journals.ac.za

e-Lexicography. The Internet, Digital Initiative and Lexicography: 54-70. London/New York: Continuum.

Verlinde, S. and G. Peeters. 2012. Data Access Revisited: The Interactive Language Tool-box. Granger, S. and M. Paquot (Eds). 2012. Electronic Lexicography: 147-162. Oxford: Oxford University Press.

Xia, L.X. and L.W. Zhai. 2016. Treatment of Entries with Chinese Characteristics in English Learner's Dictionaries: A Case Study of Oxford Advanced Learner's Dictionary, Eighth Edition. Kernerman Dictionary News 24: 12-15.

Yang, J. 2009. Chinese borrowings in English. World Englishes 28(1): 90-106.

Zgusta, L. 1989. Idle Thoughts of an Idle Fellow; or, Vaticinations on the Learners' Dictionary. Tickoo, M.L. (Ed.). 1989. Learners' Dictionaries: State of the Art: 1-9. Singapore: SEAMEO Regional Language Centre. 